\title{
Article \\ Deltamethrin-Mediated Effects on Locomotion, Respiration, Feeding, and Histological Changes in the Midgut of Spodoptera frugiperda Caterpillars
}

\author{
Germano Lopes Vinha ${ }^{1}$, Angelica Plata-Rueda ${ }^{2}$, Marcus Alvarenga Soares ${ }^{3}{ }^{\circledR}$, José Cola Zanuncio ${ }^{2}$, \\ José Eduardo Serrão ${ }^{4} \mathbb{D}$ and Luis Carlos Martínez ${ }^{4, * \mathbb{D}}$ \\ 1 Department of Crop Science, Federal University of Viçosa, Viçosa 36570000, Brazil; \\ germano.lopes.vinha@gmail.com \\ 2 Department of Entomology, Federal University of Viçosa, Viçosa 36570000, Brazil; \\ plata.angelica@gmail.com (A.P.-R.); zanuncio@ufv.br (J.C.Z.) \\ 3 Department of Crop Production, Federal University of Vales Jequitinhonha and Mucuri, \\ Diamantina 39100000, Brazil; marcus.alvarenga@ufvjm.edu.br \\ 4 Department of General Biology, Federal University of Viçosa, Viçosa 36570000, Brazil; jeserrao@ufv.br \\ * Correspondence: lc.martinez@outlook.com; Tel.: +55-31-3899-4012
}

check for

updates

Citation: Vinha, G.L.; Plata-Rueda A.; Soares, M.A.; Zanuncio, J.C.; Serrão, J.E.; Martínez, L.C.

Deltamethrin-Mediated Effects on Locomotion, Respiration, Feeding, and Histological Changes in the Midgut of Spodoptera frugiperda Caterpillars. Insects 2021, 12, 483. https://doi.org/10.3390/ insects12060483

Academic Editor: Hanafy Ismail

Received: 23 April 2021

Accepted: 21 May 2021

Published: 22 May 2021

Publisher's Note: MDPI stays neutral with regard to jurisdictional claims in published maps and institutional affiliations.

Copyright: (c) 2021 by the authors Licensee MDPI, Basel, Switzerland. This article is an open access article distributed under the terms and conditions of the Creative Commons Attribution (CC BY) license (https:// creativecommons.org/licenses/by/ $4.0 /)$.
Simple Summary: Spodoptera frugiperda is controlled mainly with chemical insecticides. Toxicity, survival, respiration, mobility, anti-feeding effect, and histology of the midgut of $S$. frugiperda caterpillars exposed to deltamethrin were evaluated. Deltamethrin was toxic to third-instar caterpillars, decreasing survival. The insecticide reduces the respiratory rate and food consumption, and causes repellency. Exposure to deltamethrin causes histological alterations in the midgut, damaging the digestive cells and peritrophic matrix. Deltamethrin is toxic to $S$. frugiperda caterpillars, causing mortality, alteration of locomotor behavior, reduced respiration and feeding, and irreversible damage to the midgut epithelium.

Abstract: Spodoptera frugiperda (J.E. Smith) (Lepidoptera: Noctuidae) is the main pest of maize crops, and effective methods for pest management are needed. The insecticidal efficacy of deltamethrin was evaluated against $S$. frugiperda for toxicity, survival, locomotion, anti-feeding, and histological changes in the midgut. Concentration-mortality bioassays confirmed that deltamethrin $\left(\mathrm{LC}_{50}=3.58 \mathrm{mg} \mathrm{mL}{ }^{-1}\right)$ is toxic to S. frugiperda caterpillars. The survival rate was $99.7 \%$ in caterpillars not exposed to deltamethrin, decreasing to $50.3 \%$ in caterpillars exposed to $\mathrm{LC}_{50}$, and $0.1 \%$ in caterpillars treated with $\mathrm{LC}_{90}$. Spodoptera frugiperda demonstrated reduced mobility on deltamethrin-treated surfaces. Deltamethrin promoted a low respiration rate of $S$. frugiperda for up to $3 \mathrm{~h}$ after insecticide exposure, displaying immobilization and inhibiting food consumption. Deltamethrin induces histological alterations (e.g., disorganization of the striated border, cytoplasm vacuolization, and cell fragmentation) in the midgut, damaging the digestive cells and peritrophic matrix, affecting digestion and nutrient absorption.

Keywords: anti-feeding effect; histopathology; repellency; respiration rate; survival; toxicity

\section{Introduction}

Spodoptera frugiperda (Smith, J.E.) (Lepidoptera: Noctuidae) is a polyphagous insect pest of crops in many parts on the world [1,2]. In Brazil, successive soybean, maize, and cotton crops are vulnerable to destruction by $S$. frugiperda [3]. For alternative pest control, biological control agents have been used [4], but with limitations to manage $S$. frugiperda [5]. Transgenic plants expressing proteins of Bacillus thuringiensis (Bt) have high specificity for target pests [6], but the occurrence of resistant populations of S. frugiperda has been reported in Argentina, Brazil, and the USA [7,8]. Additionally, pathogens such as 
Baculovirus spodoptera and S. frugiperda Nuclear Polyhedrosis Virus (SpfrNPV) have low virulence in addition to the occurrence of resistant populations [9].

In Brazil, insecticides are the main defense against $S$. frugiperda, with more than 150 active chemical substances used for its control [10], including carbamates, organochlorines, organophosphates, and pyrethroids [11]. In this scenario, deltamethrin, a neurotoxic insecticide of the pyrethroids group, acts on sodium channels in the plasma membrane of nerve cells [12,13]. This insecticide is used to control certain cotton [14], maize [15], oil palm [16], and urban pests [17]. The effect of deltamethrin on insects occurs both by contact and ingestion, and its effects were studied on Lepidoptera pests such as Neoleucinodes elegantalis Guenée (Crambidae) [18], Cnaphalocrocis medinalis Guenée (Pyralidae) [19], and Tuta absoluta Meyrick (Gelechiidae) [20].

In insects, several insecticides that act orally cause side-effects in the midgut [13,21,22]. The midgut, with functions such as nutrient absorption and digestive processes [23], cell regeneration [24], acting as a barrier against pathogens [25], and detoxification of chemical substances [26,27], is the first organ exposed to insecticides per os. Thus, insecticide molecules should cross that barrier to reach the hemolymph and spread to the target organ [28]. Therefore, the midgut is the major site of insecticide entrance in the insect body and toxic molecules first cause alterations in this organ to affect insect physiology [29-31].

Exposure to insecticides impacts negatively on non-target organs, which can change according to molecule and insect species [32]. Thus, the long-term effects of insecticides are poorly understood [33]. Deltamethrin has broad action of and toxicity against arthropods [34], being the major insecticide used to control maize pests such as $S$. frugiperda [35,36]. In this research, the action of deltamethrin on S. frugiperda survivorship, locomotion, respiration, feeding, and histotoxicity in the midgut were assessed.

\section{Materials and Methods}

\subsection{Insects}

A population of Spodoptera frugiperda (caterpillars and moths) was collected on nonBt maize fields in Viçosa, Minas Gerais, Brazil, in December of 2018. The insects were maintained in the Laboratory of Biological Control of Insects of the Federal University of Viçosa on artificial diet for five generations using standard rearing techniques [37] with a population size above 500 insects to avoid inbreeding. Different developmental stages were reared at $28 \pm 1{ }^{\circ} \mathrm{C}, 72 \pm 15 \%$ relative humidity, and 12:12 h (light:dark) photoperiod. Adults of S. frugiperda were fed on a liquid diet (10\% sucrose $+5 \%$ ascorbic acid solution $+85 \%$ water) in a moistened cotton ball. Every three days, papers with eggs were placed in plastic containers $(1 \mathrm{~L})$. Newly-hatched S. frugiperda caterpillars were kept in the plastic containers until the third-instar and subsequently individualized in PVC trays with 16 wells (Advento do Brasil, Diadema, SP, Brazil). These caterpillars were fed on a solid diet ( $31.2 \mathrm{~g}$ red beans, $12.5 \mathrm{~g}$ beer yeast, $25 \mathrm{~g}$ wheat germ, $25 \mathrm{~g}$ soybean protein, $12.5 \mathrm{~g}$ casein, $10 \mathrm{~g}$ agar, $1.2 \%$ ascorbic acid, $1.2 \%$ sorbic acid, $0.6 \%$ nipagin (methylparaben), distilled water, and $2.5 \mathrm{~mL}$ vitamin solution $(0.015 \%$ niacin, $0.03 \%$ calcium pantothenate, $0.004 \%$ thiamine, $0.008 \%$ riboflavin, $0.004 \%$ pyridoxine, $0.008 \%$ folic acid, $0.002 \%$ biotin, $0.002 \%$ inositol, and $0.004 \% \mathrm{HCl}$ )) ad libitum. Newly-emerged (24-h old) third-instar caterpillars of S. frugiperda with ca. $180 \mathrm{mg}$ weight and without malformations were utilized in the bioassays.

\subsection{Concentration-Mortality Bioassay}

Deltamethrin (Decis ${ }^{\circledR} ; 25 \mathrm{~g} \mathrm{~L}^{-1}$; Bayer Vapi Private Limited-Plot, São Paulo, Brazil) was diluted in $50 \mathrm{~mL}$ of distilled water for six concentrations $(0.39,0.78,1.56,3.12,6.25$, and $12.5 \mathrm{mg} \mathrm{mL}^{-1}$ ), where the maximum dilution was equivalent to $125 \mathrm{~g}$ a.i./ $\mathrm{L}$, corresponding with the field dose recommended for S. frugiperda. Water (distilled and deionized) was used in the control. Concentrations were prepared to evaluate the toxicity (acute or chronic) and determine the relevant toxicological endpoints, following the concentration-mortality relationship and lethal concentrations $\left(\mathrm{LC}_{25}, \mathrm{LC}_{50}, \mathrm{LC}_{75}\right.$, and $\left.\mathrm{LC}_{90}\right)$ of this insecticide. 
Caterpillars were starved for $2 \mathrm{~h}$ before starting bioassay. Each solution $(1 \mu \mathrm{L})$ was applied into $125 \mathrm{mg}$ of artificial diet using an Eppendorf micropipette (1-10 $\mu \mathrm{L}$, Eppendorf, Hamburg, Germany), which was supplied for the caterpillars during the first day. After this, for caterpillars feeding on the untreated or treated diet by $24 \mathrm{~h}$, a new artificial diet without insecticide was supplied during the evaluation time of the experiment. Thirty third-instar caterpillars of S. frugiperda were individualized in Petri dishes $(90 \times 15 \mathrm{~mm})$ and used for each concentration bioassay with three replications, following a completely random design. After five days of exposure, caterpillars were counted as dead if they were unable to walk when prodded with a brush.

\subsection{Survival Bioassay}

Caterpillars of S. frugiperda were individualized in Petri dishes and exposed to LCs $\left(\mathrm{LC}_{25}, \mathrm{LC}_{50}, \mathrm{LC}_{75}\right.$, and $\left.\mathrm{LC}_{90}\right)$ of deltamethrin, determined by the concentration-mortality bioassay, in addition to the control with distilled and deionized water. Exposure procedures and insect conditions followed the same described for the concentration-mortality bioassay. Three replications of 30 caterpillars per lethal concentration were performed to determine the lethal time and the live insects recorded every $12 \mathrm{~h}$ for five days.

\subsection{Locomotor Activity}

Spodoptera frugiperda caterpillars were individually placed in a Petri dish $90 \times 15 \mathrm{~mm}$ with a filter paper disc (Whatman No. 1) on the bottom (arena). The inner part of the top of the Petri dish was coated with Teflon ${ }^{\circledR}$ PTFE (Dupont de Nemours Inc., Wilmington, DE, USA) to avoid insect escape. Behavioral response bioassays were performed in arenas half-treated with $250 \mu \mathrm{L}$ of deltamethrin $\left(\mathrm{LC}_{50}\right.$ or $\mathrm{LC}_{90}$ ), or control (distilled and deionized water). A caterpillar of $S$. frugiperda was released in the center of the arena half-treated with insecticide (in filter paper) and maintained for $10 \mathrm{~min}$. Twenty-five caterpillars were used per treatment, and the experimental design was completely randomized. The locomotion of each insect in the arena was registered with a digital charge-coupled device (CCD) camera. The distance traveled and the resting time of $S$. frugiperda in each half of the arena was analyzed with a video-tracking system (ViewPoint Behavior Technology, Lyon, France). Insect was assumed as repelled or irritated when it spent $<60 \mathrm{~s}$ or $50 \%$ of the time in the half of the treated area with insecticide, respectively [38].

\subsection{Respiration Rate}

Bioassay was recorded for $3 \mathrm{~h}$ in S. frugiperda caterpillars after exposure to deltamethrin $\left(\mathrm{LC}_{50}\right.$ or $\mathrm{LC}_{90}$ ), according to the procedure of the mortality-concentration bioassay and with those treated with water (distilled and deionized) used as a control. The production of carbon dioxide $\left(\mathrm{CO}_{2}\right)$ ( $\mu \mathrm{L}$ of $\mathrm{CO}_{2} \mathrm{~h}^{-1}$ /insect) was measured with a respirometer of the type $\mathrm{CO}_{2}$ TR3C Analyzer (Sable System International, Las Vegas, EUA) [39]. Three $S$. frugiperda caterpillars were introduced into a $25 \mathrm{~mL}$ glass chamber in a completely closed system. The $\mathrm{CO}_{2}$ produced by one caterpillar was measured by $8 \mathrm{~h}$ at $26 \pm 3^{\circ} \mathrm{C}$ after insect acclimatization. The oxygen gas was injected through the glass chamber for $2 \mathrm{~min}$ at a

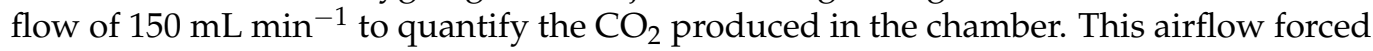
the $\mathrm{CO}_{2}$ molecules to pass through an infrared reader coupled to the system, allowing continuous measurement of the $\mathrm{CO}_{2}$ produced by insects in each chamber. Spodoptera frugiperda caterpillars, before and after the experiment, were weighed on an analytical scale (Sartorius BP 210D, Göttingen, Germany) and those with similar weight were evaluated. A total of fifteen caterpillars were used per insecticide $\left(\mathrm{LC}_{50}\right.$ and $\left.\mathrm{LC}_{90}\right)$ concentration and control.

\subsection{Anti-Feeding Effect}

The application of the concentrations was carried out by the feeding method using maize leaves. Pieces of maize leaves $(20 \times 20 \mathrm{~mm})$ were sterilized with $5 \%$ sodium hypochlorite, washed thrice with water (distilled and deionized), and dried at room 
temperature. Then, the pieces of maize leaf were soaked for $10 \mathrm{~s}$ in the $\mathrm{LC}_{50}$ and $\mathrm{LC}_{90}$ of deltamethrin and air dried for $1 \mathrm{~h}$. Spodoptera frugiperda caterpillars were individualized in Petri dishes and fed on a piece of maize leaf treated with the insecticide or untreated (using distilled and deionized water as control). The caterpillar was in contact with maize leaf for $3 \mathrm{~h}$ and, subsequently, the piece was photographed with a Nikon D40 digital photographic camera (Nikon Corporation, Tokyo, Japan) with $15 \mathrm{~cm}$ macro focus, natural, and SB-700 Nikon flourishing light. The photos were analyzed with the QUANT v. 1.0 software (Federal University of Viçosa, Viçosa, MG, Brazil). The leaf area consumed by caterpillar was measured in $\mathrm{mm}^{2}$ with pixels based on the RGB histogram (red, $763 \mathrm{~nm}$; green, $581.6 \mathrm{~nm}$; blue, $467.5 \mathrm{~nm}$ ). A total of fifteen caterpillars were used for LCs ( $\mathrm{LC}_{50}$ and $\mathrm{LC}_{90}$ ) of deltamethrin and control.

\subsection{Histopathology}

Ten third-instar caterpillars of $S$. frugiperda were exposed to $\mathrm{LC}_{50}$ of deltamethrin via ingestion, in addition to control (distilled and deionized water), for 3, 6, 12, and $24 \mathrm{~h}$. The insects were anesthetized at $-4{ }^{\circ} \mathrm{C}$ for $1 \mathrm{~min}$, the midguts dissected in a saline solution for insects $(0.1 \mathrm{M} \mathrm{NaCl}, 0.1 \mathrm{M} \mathrm{KH} 2 \mathrm{PO} 4,0.1 \mathrm{M} \mathrm{Na} 2 \mathrm{HPO} 4)$, and fixed to Zamboni solution for $6 \mathrm{~h}$ at $4{ }^{\circ} \mathrm{C}$. The midguts were dehydrated in a graded ethanol series $(70,80,90$ and $95 \%)$ and embedded in Leica historesin Leica (Leica Microsystems Inc., Buffalo Grove, IL, USA). Then, slices with $3 \mu \mathrm{m}$ thickness were sectioned in a Leica RM2255 microtome, stained with H\&S (hematoxylin-eosin), and observed under an Olympus BX-53 light microscope (Olympus Deutschland, Hamburg, Germany).

\subsection{Statistical Analysis}

The concentration-mortality curves were estimated by submitting the mortality data to Probit analysis, using the PROC PROBIT procedure with SAS v. 9.0 software. Timemortality data were analyzed with the Kaplan-Meier survival analysis with Origin Pro v. 9.1 software. Data from the S. frugiperda caterpillars that remained alive at end of the experimental period were censored. The locomotor activity and anti-feeding effect were evaluated by analysis of variance (ANOVA) and means compared with Tukey's (HSD; honestly significant difference) test $(p<00.5)$. A two-way ANOVA followed by Tukey's HSD test $(p<00.5)$ were used to analyze the respiration rate data with treatments, time, and treatments $\times$ time interaction as fixed effects. Data analysis on locomotor activity, respiration rate, and anti-feeding effect were arcsine-transformed to satisfy assumptions of normality and homoscedasticity with the SAS v. 9.0 software.

\section{Results}

\subsection{Concentration-Mortality Bioassay}

Lethal toxicity results of deltamethrin on S. frugiperda caterpillars are shown in Table 1. From the Probit analysis, the $\mathrm{LC}_{50}$ was estimated at $3.58 \mathrm{mg} \mathrm{mL}^{-1}$ with a $95 \%$ confidence interval of $3.25-3.90 \mathrm{mg} \mathrm{mL}^{-1}$, whereas the $\mathrm{LC}_{90}$ of deltamethrin was 5.65 and 5.061-6.69 $\mathrm{mg} \mathrm{mL}^{-1}$, respectively. Mortality in the control was $<1 \%$.

Table 1. Lethal concentration of deltamethrin against Spodoptera frugiperda caterpillars after 5 days exposure, obtained from Probit analysis $(\mathrm{df}=5$, slope $\pm \mathrm{SE}=6.364 \pm 0.53$, intercept $=3.519)$.

\begin{tabular}{ccccc}
\hline No. Insects & $\begin{array}{c}\text { Lethal } \\
\text { Concentration (LC) }\end{array}$ & $\begin{array}{c}\text { Estimated } \\
\text { Concentration } \\
\left.\mathbf{( m g ~ m L}^{-1}\right)\end{array}$ & $\begin{array}{c}\mathbf{9 5 \%} \text { Confidence } \\
\left.\text { Interval (mg mL } \mathbf{~ m}^{-1}\right)\end{array}$ & $\boldsymbol{\chi}^{\mathbf{2}}(\boldsymbol{p}$-Value) \\
\hline 90 & $\mathrm{LC}_{25}$ & 2.858 & $2.459-3.167$ & \\
90 & $\mathrm{LC}_{50}$ & 3.588 & $3.251-3.909$ & $1.58(0.90)$ \\
90 & $\mathrm{LC}_{75}$ & 4.504 & $4.128-5.026$ & \\
90 & $\mathrm{LC} 90$ & 5.653 & $5.061-6.690$ & \\
\hline
\end{tabular}




\subsection{Survival Bioassay}

The survival analysis of $S$. frugiperda caterpillars exposed to the different LCs of deltamethrin indicated significant differences during the five days of evaluation (test of log-rank $\chi^{2}=64.55, \mathrm{df}=4, p<0.001$ ). Survival was $99.7 \%$ in the control, decreasing to $71.8 \%$ with $\mathrm{LC}_{25}, 50.3 \%$ with $\mathrm{LC}_{50}$, and $0.1 \%$ with $\mathrm{LC}_{75}$ and $\mathrm{LC}_{90}$ (Figure 1 ).

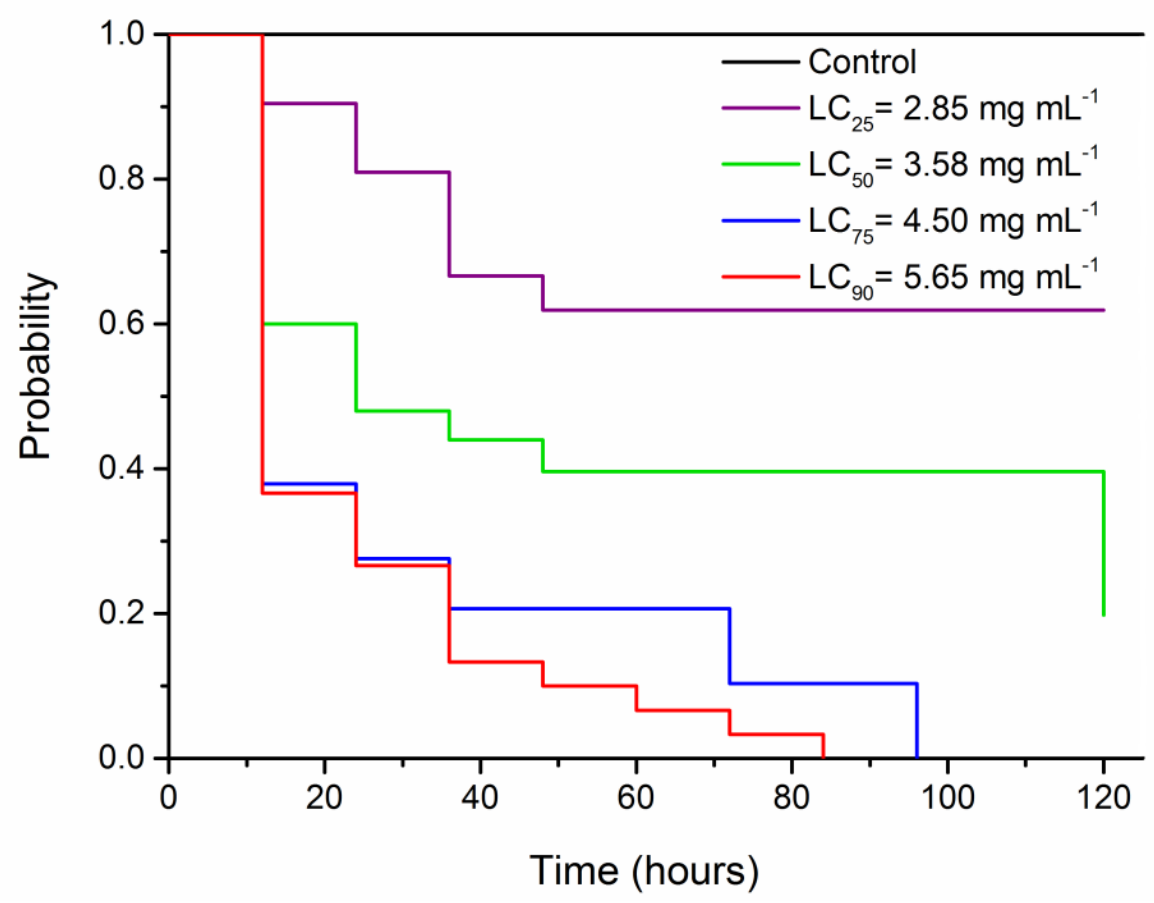

Figure 1. Survival curves of Spodoptera frugiperda caterpillars exposed to different lethal concentrations of deltamethrin, subjected to survival analyses using the Kaplan-Meier estimator log-rank test $\left(\chi^{2}=64.55, \mathrm{df}=4, p<0.001\right)$.

\subsection{Locomotor Activity}

Representative walking tracks for S. frugiperda released in the half-treated arenas are observed in Figure 2A. Locomotion behavior of $S$. frugiperda caterpillars in half-treated arenas differed between the control and $\mathrm{LCs}\left(\mathrm{LC}_{50}\right.$ and $\left.\mathrm{LC}_{90}\right)$ of deltamethrin. The resting time was higher in the control with $358 \pm 41 \mathrm{~s}$, followed by $\mathrm{LC}_{90}$ with $224 \pm 26 \mathrm{~s}$, and $\mathrm{LC}_{50}$ with $219 \pm 27 \mathrm{~s}\left(\mathrm{~F}_{2,24}=4.59, p<0.021\right)$. The distance traveled was higher in the control with $377 \pm 44 \mathrm{~cm}$, followed by LC 50 with $256 \pm 67 \mathrm{~cm}$, and $\mathrm{LC}_{90}$ with $154 \pm 39 \mathrm{~cm}\left(\mathrm{~F}_{2,24}=4.53\right.$, $p<0.022$ ) (Figure 2B). 


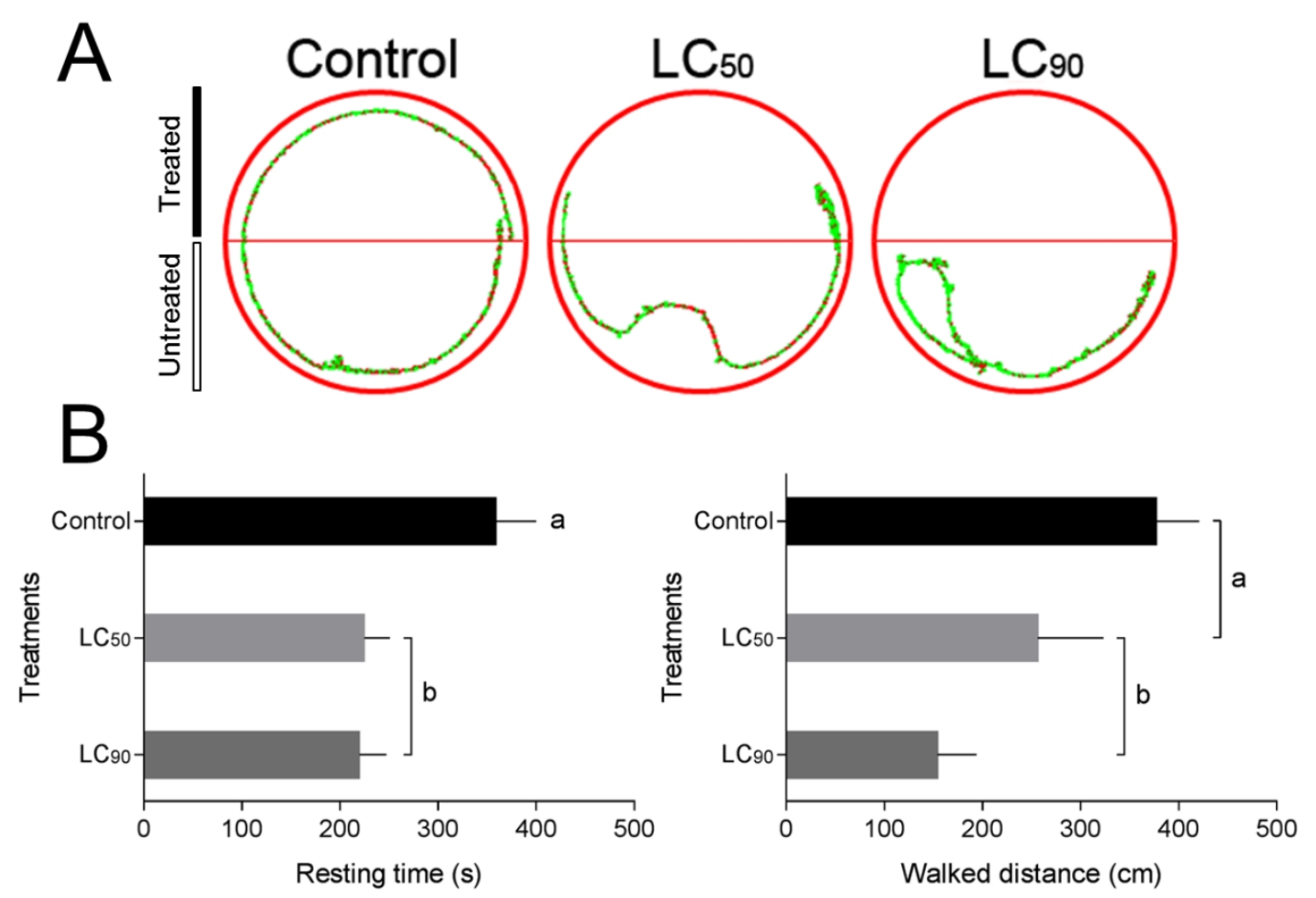

Figure 2. Behavior response of Spodoptera frugiperda caterpillars caused by deltamethrin. (A) Representative tracks showing the walking activity of $S$. frugiperda over a 10-min period on filter paper arenas half-impregnated with deltamethrin (upper half of each arena). Red tracks indicate high walking velocity; green tracks indicate low (initial) velocity. (B) Resting time and distance walked of S. frugiperda subjected to deltamethrin (control, $\mathrm{LC}_{50}$, and $\mathrm{LC}_{90}$ estimated values) for $10 \mathrm{~min}$. Treatments (mean \pm SEM) differ at $p<0.05$ (Tukey's mean separation test).

\subsection{Respiration Rate}

The respiration rate of $S$. frugiperda caterpillars treated on deltamethrin began to decrease after $1 \mathrm{~h}$, from $14.7 \mu \mathrm{L}$ of $\mathrm{CO}_{2} \mathrm{~h}^{-1}$ in the control, to $13.5 \mu \mathrm{L}$ of $\mathrm{CO}_{2} \mathrm{~h}^{-1}$ in $\mathrm{LC}_{50}$, and $13.1 \mu \mathrm{L}$ of $\mathrm{CO}_{2} \mathrm{~h}^{-1}$ in $\mathrm{LC}_{90}$. After $3 \mathrm{~h}$ of exposure to deltamethrin, there were different respiration rates between treatments $\left(\mathrm{F}_{2,84}=9.44, p<0.002\right)$, exposure time $\left(\mathrm{F}_{2,84}=97.4\right.$, $p<0.001)$, and treatment $\times$ time interaction $\left(\mathrm{F}_{2,84}=17.1, p<0.001\right)$, with $13.1 \mu \mathrm{L}$ of $\mathrm{CO}_{2} \mathrm{~h}^{-1}$ in the control, $11.8 \mu \mathrm{L}$ of $\mathrm{CO}_{2} \mathrm{~h}^{-1}$ in $\mathrm{LC}_{50}$, and $9.51 \mu \mathrm{L}$ of $\mathrm{CO}_{2} \mathrm{~h}^{-1}$ in $\mathrm{LC}_{90}$ (Figure 3, Table 2).

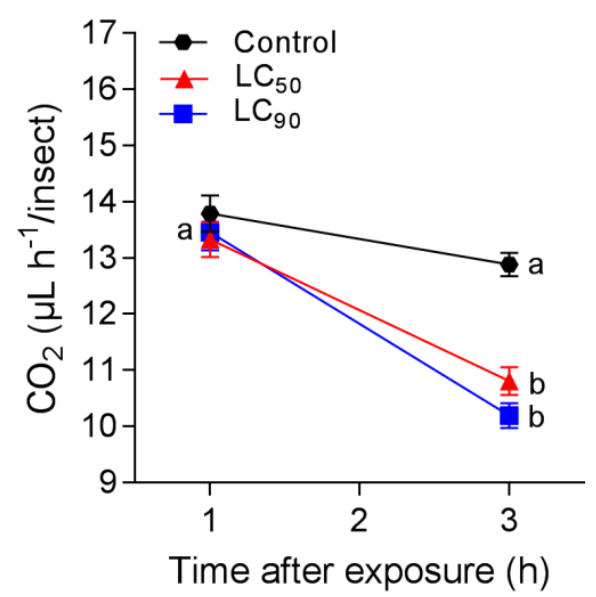

Figure 3. Respiration rate of Spodoptera frugiperda caterpillars exposed to deltamethrin (control, $\mathrm{LC}_{50}$, and LC $_{90}$ estimated values) for $3 \mathrm{~h}$. Treatments (mean \pm SEM) differ at $p<0.05$ (Tukey's mean separation test). 
Table 2. Two-way ANOVA for respiration rate of Spodoptera frugiperda caterpillars upon exposure to lethal concentrations ( $\mathrm{LC}_{50}$ and $\mathrm{LC}_{90}$ ) of deltamethrin for two times. DF = degrees of freedom; $\mathrm{SS}=$ sum of squares; $\mathrm{MS}=$ mean square; $\mathrm{n}=$ numerator; $\mathrm{d}=$ denominator; $p$ = probability of significance; $\alpha=0.05$.

\begin{tabular}{cccccc}
\hline ANOVA Table & SS & DF & MS & $\boldsymbol{F}$ (DFn DFd) & $p$-Value \\
\hline Treatments & 39.31 & 2 & 19.65 & $F(2,84)=9.44$ & $<0.002$ \\
Time & 111.9 & 1 & 111.9 & $F(1,84)=97.4$ & $<0.001$ \\
Treatments $\times$ time & 21.68 & 2 & 10.84 & $F(2,84)=17.1$ & $<0.001$ \\
Residual & 96.47 & 84 & 1.148 & & \\
Total & 269.3 & 89 & & & \\
\hline
\end{tabular}

\subsection{Anti-Feeding Effect}

The leaf area consumed by S. frugiperda caterpillars was different in the treatments $\left(\mathrm{F}_{2,14}=6.65, p<0.001\right)$, being higher in the control $\left(77.1 \pm 19 \mathrm{~mm}^{2}\right)$ than in those exposed to $\mathrm{CL}_{90}\left(5.26 \pm 2 \mathrm{~mm}^{2}\right)$ and $\mathrm{CL}_{50}\left(3.08 \pm 1 \mathrm{~mm}^{2}\right)$ of deltamethrin (Figure 4$)$.
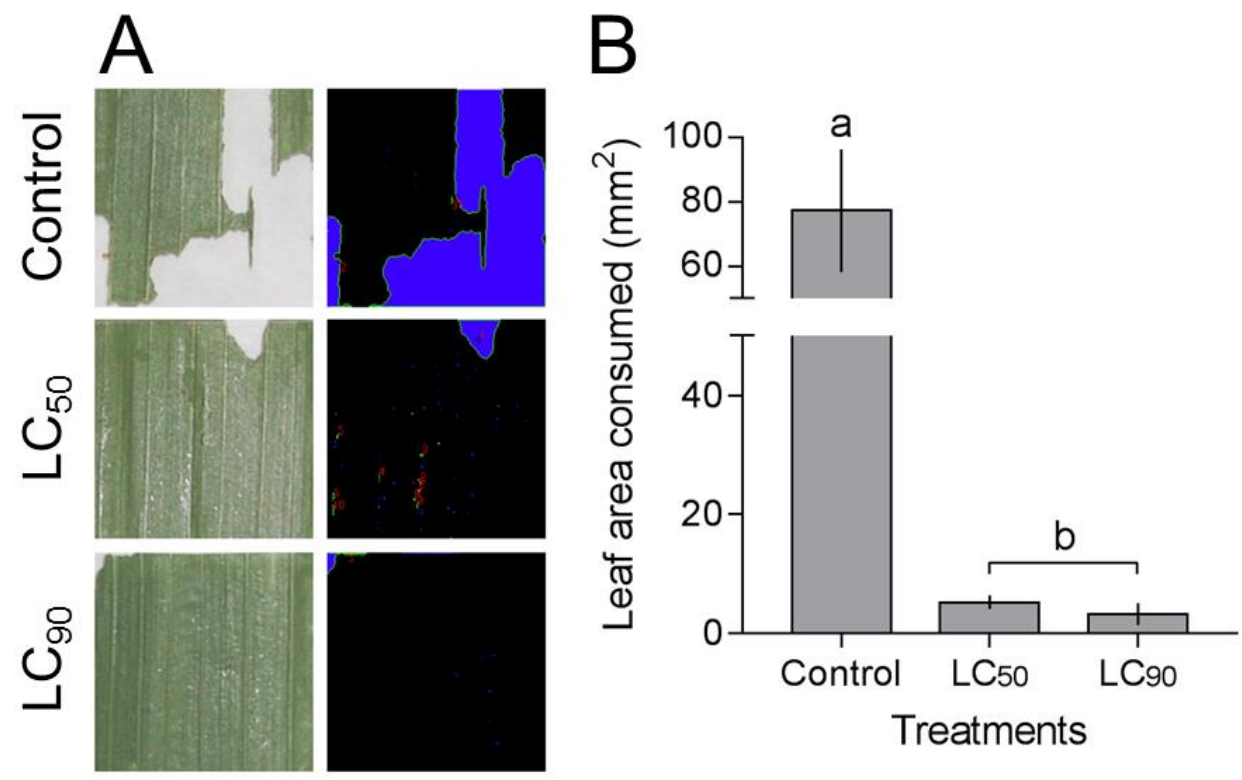

Figure 4. Anti-feeding effect caused by deltamethrin on Spodoptera frugiperda caterpillar. (A) Leaf section $(20 \times 20 \mathrm{~mm})$ treated with distilled water and insecticide submitted to color binarization (black and blue) with identification and quantification of area consumed. (B) Leaf area consumed by $S$. frugiperda exposed to deltamethrin (control, $\mathrm{LC}_{50}$, and $\mathrm{LC}_{90}$ estimated values). Treatments (mean $\pm \mathrm{SEM}$ ) differ at $p<0.05$ (Tukey's mean separation test).

\subsection{Histopathology}

In the control, the midgut of $S$. frugiperda had a single epithelial layer of digestive and goblet cells. Digestive cells have homogeneous cytoplasm and well-developed nuclei with predominance of decondensed chromatin. The apical surface of these cells had an evidently striated border and the midgut lumen showed a well-developed peritrophic matrix (Figure 5A,F). The basal surface of these cells was lined by muscle layers (Figure 5K). After $3 \mathrm{~h}$ of the insect being exposed to $\mathrm{LC}_{50}$ of deltamethrin, the apical surface of the midgut epithelium was irregular and the cytoplasm was highly vacuolized (Figure 5B,G,L). Protrusions of the apical epithelium towards the gut lumen, high vacuolization in the cytoplasm, and apocrine secretion were found after $6 \mathrm{~h}$ of insecticide exposure (Figure 5C,H,M). After $12 \mathrm{~h}$ exposure, there was cell vacuolization, disorganization of the striated border, cell fragmentation, nuclei with condensed chromatin, and disruption of the peritrophic matrix (Figure 5D,I,N). These features were similar to those found after $24 \mathrm{~h}$ of oral exposure to deltamethrin (Figure 5E,J,O). The goblet cells have a large cavity of the apical surface 
forming a well-developed extracellular compartment, without modifications in the insects exposed to deltamethrin (Figure $5 \mathrm{H}$ ).

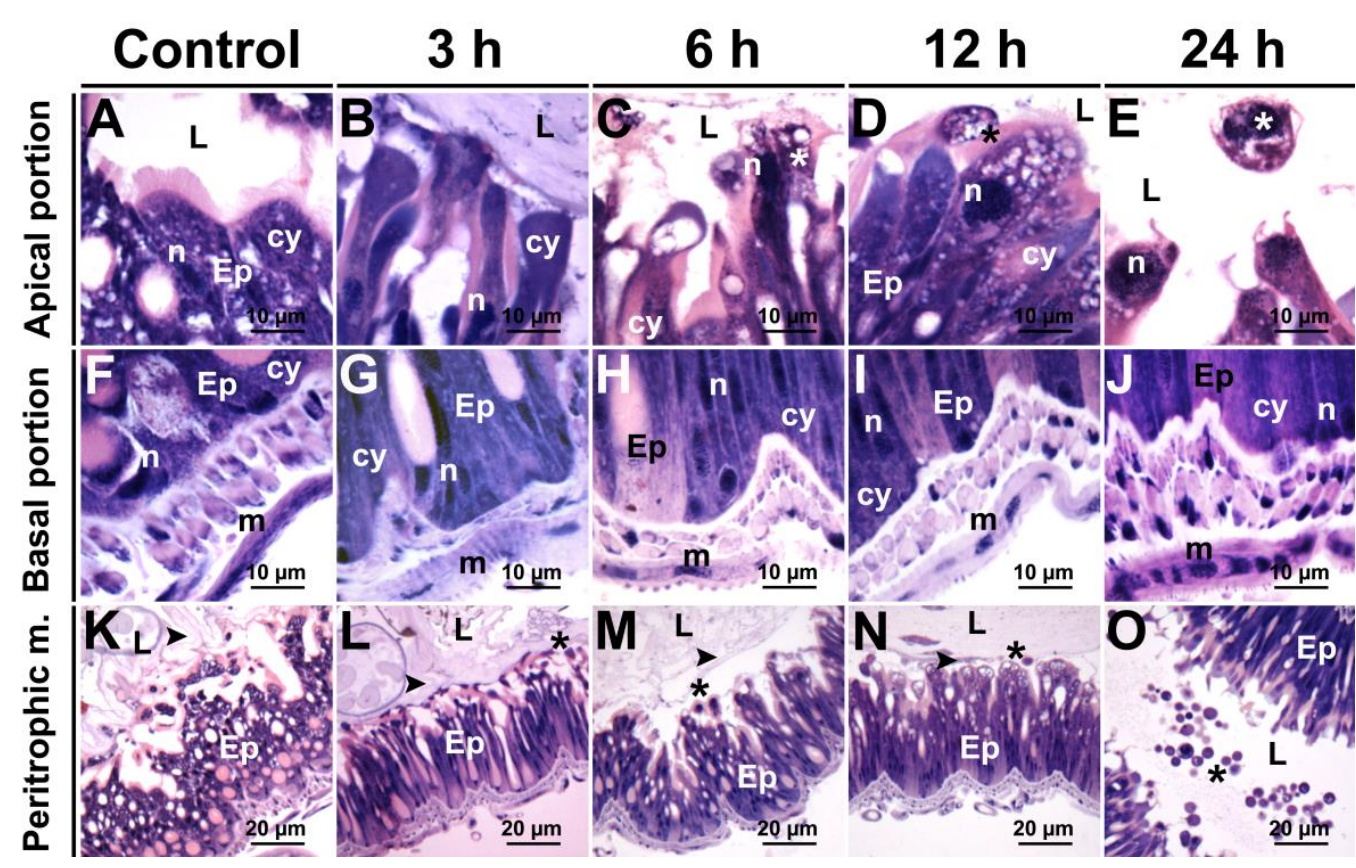

Figure 5. Light micrographs of the midgut of Spodoptera frugiperda caterpillars 3, 6, 12, and $24 \mathrm{~h}$ after exposure to deltamethrin. (A-E) Apical portion of digestive cells showing sequential effects with increase in vacuolization. (F-J) Basal portion of digestive cells showing sequential effects with increase in vacuolization. (K-O) Details showing sequential effects in the peritrophic matrix. Epithelium (Ep), lumen $(\mathbf{L})$, peritrophic matrix $(\bullet)$, cell protrusion $\left.{ }^{*}\right)$. Control $(\mathbf{A}, \mathbf{F}, \mathbf{K})$.

\section{Discussion}

The action of deltamethrin on $S$. frugiperda caterpillars was determined from bioassays performed in the laboratory, with an intense effect via ingestion. The insecticide caused concentration-dependent mortality of $S$. frugiperda, as reported for other insects $[12,40,41]$. Spodoptera frugiperda caterpillars exposed to $\mathrm{LC}_{50}$ and $\mathrm{LC}_{90}$ of deltamethrin changed their locomotion activity. Some individuals gradually lost mobility without signs of recovery when exposed to LC90. In this case, the symptoms in S. frugiperda agree with the effect caused by pyrethroid insecticides, which act on voltage-gated sodium channels on the axonal membrane, including those in the motor neuron $[13,16]$. The susceptibility to deltamethrin of other Noctuidae, such as Chrysodeixis includens Walker [42], Helicoverpa armigera Hübner [14], and Spodoptera litura Fabricius [43], varies according to the exposure method (contact or ingestion), but deltamethrin, in a reduced concentration $\left(\mathrm{LC}_{50}=3.58 \mathrm{mg} \mathrm{mL}^{-1}\right)$, is sufficient to cause toxicity to $S$. frugiperda by ingestion.

The high variation in $S$. frugiperda survival is mediated by the deltamethrin interaction with target sites in the nervous system, necessary to induce chronic toxicity. Time periods to induce mortality in S. frugiperda by this insecticide were after $80 \mathrm{~h}$ with $\mathrm{LC}_{90}$ and $120 \mathrm{~h}$ with $\mathrm{LC}_{50}$. These time differences occur because the midgut is a barrier to deltamethrin reaching the target sites. The long periods to the LCs of deltamethrin mean that S. frugiperda mortality obtained here may be misinterpreted as compromising the insecticide performance, since during pest outbreaks rapid pest mortality is expected $[12,16]$, but deltamethrin inhibits the growth [40] and development [41] and interrupts the life cycle [43] of insects, and its effect against $S$. frugiperda suggests toxic effects with a possible population decrease during the first days of infestation, which is important for crop protection.

The low resting time and walked distance by $S$. frugiperda caused by deltamethrin shows its effect on the locomotion behavior of this insect, probably due to its action in the nervous system inhibiting the insect's mobility $[13,16]$. The behavioral responses of 
insects exposed to pesticides [38,39,44] may affect substrate recognition [45], olfactory orientation[46], and foraging [41]. Changes in locomotion behavior by deltamethrin have been reported for Anopheles harrisoni, Anopheles minimus Meigan (Diptera: Culicidae) [44], Grapholita molestans Busk (Lepidoptera: Tortricidae) [47], Sitophilus granarius Linnaeus, and Sitophilus zeamais Motschulsky (Coleoptera: Curculionidae) [40]. Insect behavioral responses to prevent direct intoxication by insecticides include non-contact with insecticide (repellency) and evasion after brief contact (irritability) [48]. The non-preference of $S$. frugiperda walking in the half-arena treated with the insecticide suggests that the caterpillars avoid direct contact with deltamethrin.

Deltamethrin affected negatively the respiration of S. frugiperda, indicating physiological stress. A similar result occurs in Anticarsia gemmatalis Hübner (Lepidoptera: Noctuidae) exposed to azadirachtin [49], chlorpyrifos [50], and tebufenozide [26]. This decrease might be due to the low behavioral response and locomotor activity. Higher levels of walking activity are expected to result in metabolism with a high respiration rate $[29,51]$. The decrease in the oxygen consumption observed here may be related to the disruption of oxidative phosphorylation in respiration $[49,51,52]$, and may result in unbalanced physiology of the insect.

The decrease in the consumption of maize leaves treated with $\mathrm{LC}_{50}$ and $\mathrm{LC}_{90}$ of deltamethrin suggests an anti-feeding effect, probably by the neurotoxic action of deltamethrin [14] causing paralysis [14,16] and, consequently, cessation of food. The rapid intoxication of $S$. frugiperda, after exposure to deltamethrin, may reduce the damage caused in plants, similar to that reported for adults of Popillia japonica Newman (Coleoptera: Scarabaeidae) exposed to leaves of Tilia cordata Mill. (Malvales: Malvaceae) treated with deltamethrin, with reduced food consumption in 96.8\% [53]. Some insecticides inhibit feeding before the target insects die, and rapid action is essential for the protection of agricultural systems $[11,50]$. Deltamethrin and other pyrethroids reduce insect damage in maize crop as demonstrated by Helicoverpa zea Boddie (Lepidoptera: Noctuidae) [54] and Ostrinia nubilalis Hübner (Lepidoptera: Crambidae) [55].

The exposure per os to deltamethrin induces epithelial alterations in the midgut of $S$. frugiperda in short periods, although this insecticide has a neurotoxic action mode [13,21], suggesting that the midgut is a potential target organ for this insecticide. The histological changes found are characteristic of a degenerative cellular process, such as disorganization of the striated border, cytoplasm vacuolization, and cell fragmentation. In the midgut, cell degeneration is described in other insects, such as Anticarsia gemmatalis Hübner (Lepidoptera: Noctuidae) in response to chlorpyrifos [50] and chlorantraniliprole [51], Apis mellifera Linnaeus (Hymenoptera: Apidae) to iprodione [56] and spiromesifen [57], Podisus nigrispinus Dallas (Hemiptera: Pentatomidae) to permethrin [21] and spinosad [22], and Aedes aegypti (Diptera: Culicidae) to pyriproxyfen [30]. The histo-toxic effects in the midgut of $S$. frugiperda exposed to deltamethrin are mainly damages in the striated border of the digestive cells and in the peritrophic matrix. The striated border of the midgut increases the cell surface for the transport of substances [56-58], whereas the luminal peritrophic matrix is a physical barrier against mechanical injuries, pathogens and xenobiotic agents, and controls digestion $[58,59]$. The peritrophic matrix has its components (chitin and proteins) produced by the digestive cells and released by the microvilli of these cells [60-62]. Thus, the damage in these microvilli and in the peritrophic matrix formation may compromise the digestive process in S. frugiperda caterpillars.

Overall, our findings show that ingested deltamethrin has potential deleterious effects on S. frugiperda behavior and physiology. The application of insecticides in fields has a direct killing effect on pests exposed to lethal doses, but also results, to a certain extent, in the survival of individuals exposed to low doses over time. Some pesticides have been reported to contaminate plants from the cultivation of treated crops in the same field in previous years $[63,64]$, so that pests may ingest lower doses of pesticides, and the changes in physiological and behavioral parameters evaluated here can be used to assess and predict the toxicity and potential efficacy of deltamethrin in the control of S. frugiperda. 


\section{Conclusions}

This findings or this study show that deltamethrin is toxic when ingested by $S$. frugiperda caterpillars, changing their locomotion behavior, feeding, and respiration, which may be adequate to kill or interrupt the development of this pest. Thus, the findings reveal that deltamethrin histological alterations, such as disorganization of the striated border, cytoplasm vacuolization, and cell fragmentation, damage the midgut and compromise the digestive processes.

Author Contributions: Conceptualization, G.L.V., A.P.-R., J.E.S. and L.C.M.; methodology, G.L.V., A.P.-R., J.E.S. and L.C.M.; formal analysis, G.L.V., A.P.-R., J.E.S. and L.C.M.; investigation, G.L.V., A.P.-R., J.E.S. and L.C.M.; resources, M.A.S., J.C.Z., J.E.S. and L.C.M.; writing, G.L.V., A.P.-R., M.A.S., J.C.Z., J.E.S. and L.C.M.; supervision, A.P.-R., J.C.Z., J.E.S. and L.C.M.; project administration, A.P.-R., J.C.Z., J.E.S. and L.C.M.; funding acquisition, M.A.S., J.C.Z., J.E.S. and L.C.M. All authors have read and agreed to the published version of the manuscript.

Funding: This research was funded by the Brazilian research agencies Conselho Nacional de Desenvolvimento Científico e Tecnológico (CNPq) (grant number 305165/2013-5), Coordenação de Aperfeiçoamento de Pessoal de Nível Superior (CAPES) (grant number 2815/11), and Fundação de Amparo a Pesquisa do Estado de Minas Gerais (FAPEMIG) (grant number APQ-01079-13).

Institutional Review Board Statement: Not applicable for studies not involving humans or animals.

Informed Consent Statement: Not applicable for studies not involving humans.

Data Availability Statement: Data sharing not applicable.

Acknowledgments: In this section, you can acknowledge any support given which is not covered by the author contribution or funding sections. This may include administrative and technical support, or donations in kind (e.g., materials used for experiments).

Conflicts of Interest: The authors declare no conflict of interest.

\section{References}

1. Barros, E.M.; Torres, J.B.; Ruberson, J.R.; Oliveira, M.D. Development of Spodoptera frugiperda on different hosts and damage to reproductive structures in cotton. Entomol. Exp. Appl. 2010, 137, 237-245. [CrossRef]

2. Montezano, D.G.; Sosa-Gómez, D.R.; Roque-Specht, V.F.; Sousa-Silveira, J.C.; Paula-Moraes, S.V.; Peterson, J.A.; Hunt, T.E. Host plants of Spodoptera frugiperda (Lepidoptera: Noctuidade) in the Americas. Afr. Entomol. 2018, 26, 286-300. [CrossRef]

3. Martinelli, S.; Clark, P.L.; Zucchi, M.I.; Silva-Filho, M.C.; Foster, J.E.; Omoto, C. Genetic structure and molecular variability of Spodoptera frugiperda (Lepidoptera: Noctuidae) collected in maize and cotton fields in Brazil. Bull. Entomol. Res. 2007, 97, 225-231. [CrossRef]

4. Shields, M.W.; Johnson, A.C.; Pandey, S.; Cullen, R.; González-Chang, M.; Wratten, S.D.; Gurr, G.M. History, current situation and challenges for conservation biological control. Biol. Control 2019, 131, 25-35. [CrossRef]

5. Campos, J.M.; Martínez, L.C.; Plata-Rueda, A.; Weigand, W.; Zanuncio, J.C.; Serrão, J.E. Insecticide potential of two saliva components of the predatory bug Podisus nigrispinus (Heteroptera: Pentatomidae) against Spodoptera frugiperda (Lepidoptera: Noctuidae) caterpillars. Toxin Rev. 2021, 1-10. [CrossRef]

6. Brookes, G.; Barfoot, P. Global income and production impacts of using GM crop technology 1996-2014. GM Crop Food 2016, 7, 38-77. [CrossRef]

7. Anderson, J.A.; Ellsworth, P.C.; Faria, J.C.; Head, G.P.; Owen, M.D.K.; Pilcher, C.D.; Shelton, A.M.; Meissle, M. Genetically engineered crops: Importance of diversified integrated pest management for agricultural sustainability. Front. Bioeng. Biotech. 2019, 7, 1-24. [CrossRef] [PubMed]

8. Schneider, A.M.; Gontijo, L.M.; Costa, L.L. Impact of Bt sweet corn on Lepidoptera pests in Midwestern Brazil. Sci. Agr. 2019, 73, 214-219. [CrossRef]

9. Fuxa, J.R.; Richter, A.R. Response of nuclear polyhedrosis virus-resistant Spodoptera frugiperda larvae to other pathogens and to chemical insecticides. J. Invertebr. Pathol. 1990, 55, 272-277. [CrossRef]

10. Agrofit. Sistemas de Agrotóxicos Fitossanitários. 2018. Available online: http://extranet.agricultura.gov.br/agrofit_cons/ principal_agrofit_cons (accessed on 6 August 2018).

11. Burtet, L.M.; Bernardi, O.; Melo, A.A.; Pes, M.P.; Strahl, T.T.; Guedes, J.V. Managing fall armyworm, Spodoptera frugiperda (Lepidoptera: Noctuidae), with Bt maize and insecticides in southern Brazil. Pest Manag. Sci. 2017, 73, 2569-2577. [CrossRef]

12. Martínez, L.C.; Plata-Rueda, A.; Zanuncio, J.C.; Serrão, J.E. Comparative toxicity of six insecticides on the Rhinoceros beetle (Coleoptera: Scarabaeidae). Fla. Entomol. 2014, 97, 1056-1062. [CrossRef] 
13. Arthidoro de Castro, M.B.A.; Martínez, L.C.; Serra, R.S.; Cossolin, J.F.S.; Serrão, J.E. Cytotoxic effects on the midgut, hypopharyngeal, glands and brain of Apis mellifera honey bee workers exposed to chronic concentrations of lambda-cyhalothrin. Chemosphere 2020, 248, 126075. [CrossRef]

14. Ahmad, M. Potentiation/antagonism of deltamethrin and cypermethrins with organophosphate insecticides in the cotton bollworm, Helicoverpa armigera (Lepidoptera: Noctuidae). Pestic. Biochem. Physiol. 2004, 80, 31-42. [CrossRef]

15. Beres, P.K.; Kucharczyk, H.; Gorski, D. Effects of insecticides used against the European corn borer on thrips abundance on maize. Plant Prot. Sci. 2017, 53, 44-49.

16. Martínez, L.C.; Plata-Rueda, A.; Rodríguez-Dimaté, F.A.; Campos, J.M.; Santos Júnior, V.C.D.; Rolim, G.D.S.; Fernandes, F.L.; Silva, W.M.; Wilcken, C.F.; Zanuncio, J.C.; et al. Exposure to insecticides reduces populations of Rhynchophorus palmarum in oil palm plantations with Bud Rot disease. Insects 2019, 10, 111. [CrossRef]

17. Richards, S.L.; Volkan, J.K.; Balanay, J.A.G.; Vandock, K. Evaluation of bifenthrin and deltamethrin barrier sprays for mosquito control in eastern North Carolina. J. Med. Entomol. 2017, 54, 1659-1665. [CrossRef] [PubMed]

18. Silva, R.S.; Arcanjo, L.P.; Soares, J.R.S.; Ferreira, D.O.; Serrão, J.E.; Martins, J.C.; Costa, A.H.; Picanço, M.C. Insecticide toxicity to the borer Neoleucinodes elegantalis (Guenée) (Lepidoptera: Crambidae): Developmental and egg-laying effects. Neotrop. Entomol. 2018, 47, 318-325. [CrossRef] [PubMed]

19. Yang, Y.J.; Wang, C.Y.; Xu, H.X.; Lu, Z.X. Sublethal effects of four insecticides on folding and spinning behavior in the rice leaffolder, Cnaphalocrocis medinalis (Guenee) (Lepidoptera Pyralidae). Pest Manag. Sci. 2018, 74, 658-664. [CrossRef] [PubMed]

20. Zibaee, I.; Mahmood, K.; Esmaeily, M.; Bandani, A.R. Kristensen. Organophosphate and pyrethroid resistances in the tomato leaf mine Tuta absoluta (Lepidoptera: Gelechiidae) from Iran. J. Appl. Entomol. 2017, 142, 181-191. [CrossRef]

21. Martínez, L.C.; Plata-Rueda, A.; da Silva Neves, G.; Gonçalves, W.G.; Zanuncio, J.C.; Bozdoğan, H.; Serrão, J.E. Permethrin induces histological and cytological changes in the midgut of the predatory bug, Podisus nigrispinus. Chemosphere 2018, 212, 629-637. [CrossRef]

22. Santos-Junior, V.C.; Martínez, L.C.; Plata-Rueda, A.; Bozdogan, H.; Zanuncio, J.C.; Serrão, J.E. Exposure to spinosad induces histopathological and cytotoxic effects on the salivary complex of the non-target predator Podisus nigrispinus. Chemosphere 2019, 225, 688-695. [CrossRef] [PubMed]

23. Cossolin, J.F.S.; Lopes, D.R.G.; Martínez, L.C.; Santos, H.C.P.; Fiaz, M.; Pereira, M.J.B.; Vivan, L.M.; Mantovani, H.C.; Serrão, J.E. Morphology and composition of the midgut bacterial community of Scaptocoris castanea Perty, 1830 (Hemiptera: Cydnidae). Cell Tissue Res. 2020, 382, 337-349. [CrossRef] [PubMed]

24. Lehane, M.; Billingsley, P. Biology of the Insect Midgut; Springer Science \& Business Media: Berlin/Heidelberg, Germany, 2012.

25. Castro, B.M.C.E.; Martinez, L.C.; Barbosa, S.G.; Serrão, J.E.; Wilcken, C.F.; Soares, M.A.; Silva, A.A.D.; Carvalho, A.G.D.; Zanuncio, J.C. Toxicity and cytopathology mediated by Bacillus thuringiensis in the midgut of Anticarsia gemmatalis (Lepidoptera: Noctuidae). Sci. Rep. 2019, 9, 6667. [CrossRef] [PubMed]

26. Fiaz, M.; Martínez, L.C.; Plata-Rueda, A.; Gonçalves, W.G.; Shareef, M.; Zanuncio, J.C.; Serrão, J.E. Toxicological and morphological effects of tebufenozide on Anticarsia gemmatalis (Lepidoptera: Noctuidae) larvae. Chemosphere 2018, 212, 237-345. [CrossRef]

27. Martínez, L.C.; Plata-Rueda, A.; Gonçalves, W.G.; Freire, A.F.P.A.; Zanuncio, J.C.; Bozdoğan, H.; Serrão, J.E. Toxicity and cytotoxicity of the insecticide imidacloprid in the midgut of the predatory bug, Podisus nigrispinus. Ecotox. Environ. Saf. 2019, 167, 69-75. [CrossRef]

28. Denecke, S.; Swers, L.; Douris, V.; Vontas, J. How do oral insecticidal compounds cross the insect midgut epithelium? Insect Biochem. Mol. Biol. 2018, 103, 22-35. [CrossRef]

29. Fiaz, M.; Martínez, L.C.; da Silva Costa, M.; Cossolin, J.F.S.; Plata-Rueda, A.; Gonçalves, W.G.; Sant'Ana, A.E.G.; Zanuncio, J.C.; Serrão, J.E. Squamocin induce histological and ultrastructural changes in the midgut cells of Anticarsia gemmatalis (Lepidoptera: Noctuidae). Ecotox. Environ. Saf. 2018, 156, 1-8. [CrossRef]

30. Fiaz, M.; Martínez, L.C.; Plata-Rueda, A.; Gonçalves, W.G.; Souza, D.L.L.; Cossolin, J.F.S.; Carvalho, P.E.G.R.; Martins, G.F.; Serrão, J.E. Pyriproxyfen, a juvenile hormone analog, damages midgut cells and interferes with behaviors of Aedes aegypti larvae. PeerJ 2019, 7, e7489. [CrossRef]

31. Santos Junior, V.C.; Martínez, L.C.; Plata-Rueda, A.; Fernandes, F.L.; Tavares, W.S.; Zanuncio, J.C.; Serrão, J.E. Histopathological and cytotoxic changes induced by spinosad on midgut cells of the non-target predator Podisus nigrispinus Dallas (Heteroptera: Pentatomidae). Chemosphere 2020, 238, 124585. [CrossRef]

32. Cossolin, J.F.S.; Pereira, M.J.; Martínez, L.C.; Turchen, L.M.; Fiaz, M.; Bozdoğan, H.; Serrão, J.E. Cytotoxicity of Piper aduncum (Piperaceae) essential oil in brown stink bug Euchistus heros (Heteroptera: Pentatomidae). Ecotoxicology 2019, 28, 763-770. [CrossRef]

33. Plata-Rueda, A.; Martínez, L.C.; Costa, N.C.R.; Zanuncio, J.C.; Sena Fernandes, M.E.; Serrão, J.E.; Guedes, R.N.C.; Fernandes, F.L. Chlorantraniliprole-mediated effects on survival, walking abilities, and respiration in the coffee berry borer, Hypothenemus hampei. Ecotoxicol. Environ. Saf. 2019, 172, 53-58. [CrossRef] [PubMed]

34. Badji, C.A.; Guedes, R.N.C.; Silva, A.A.; Araújo, R.A. Impact of deltamethrin on arthropods in maize under conventional and no-tillage cultivation. Crop Prot. 2004, 23, 1031-1039. [CrossRef]

35. Boaventura, D.; Buer, B.; Hamaekers, N.; Maiwald, F.; Nauen, R. Toxicological and molecular profiling of insecticide resistance in a Brazilian strain of fall armyworm resistant to Bt Cry1 proteins. Pest Manag. Sci. 2020. [CrossRef] 
36. Boaventura, D.; Ulrich, J.; Lueke, B.; Bolzan, A.; Okuma, D.; Gutbrod, O.; Geibel, S.; Zeng, Q.; Dourado, P.M.; Martinelli, S.; et al. Molecular characterization of Cry1F resistance in fall armyworm, Spodoptera frugiperda from Brazil. Insect Biochem. Mol. Biol. 2020, 116, 103280. [CrossRef] [PubMed]

37. Santos-Amaya, O.F.; Tavares, C.S.; Monteiro, H.M.; Teixeira, T.P.M.; Guedes, R.N.C.; Alves, A.P.; Pereira, E.J.G. Genetic basis of Cry1F resistance in two Brazilian populations of fall armyworm, Spodoptera frugiperda. Crop Prot. 2016, 81, 154-162. [CrossRef]

38. Plata-Rueda, A.; Campos, J.M.; da Silva Rolim, G.; Martínez, L.C.; Dos Santos, M.H.; Fernandes, F.L.; Serrão, J.E.; Zanuncio, J.C. Terpenoid constituents of cinnamon and clove essential oils cause toxic effects and behavior repellency response on granary weevil, Sitophilus granarius. Ecotoxicol. Environ. Saf. 2018, 156, 263-270. [CrossRef]

39. Plata-Rueda, A.; Martínez, L.C.; Da Silva, B.K.R.; Zanuncio, J.C.; Sena Fernandes, M.E.; Serrão, J.E.; Guedes, R.N.C.; Fernandes, F.L. Exposure to cyantraniliprole causes mortality and disturbs behavioral and respiratory response in the coffee berry borer (Hypothenemus hampei). Pest Manag. Sci. 2019, 75, 2236-2241. [CrossRef]

40. Vélez, M.; Barbosa, W.F.; Quintero, J.; Chediak, M.; Guedes, R.N.C. Deltametrhin and spinosad mediated survival, activity and avoidance of the grain weevils Sitophilus granarius and S. zeamais. J. Stored Prod. Res. 2017, 74, 56-65. [CrossRef]

41. Zeng, R.; Yu, X.; Tan, X.; Ye, S.; Ding, Z. Deltamethrin affects the expression of volted-gated calcium channel $\alpha 1$ subunits and the locomotion, egg-laying, foraging behavior of Caernorhabditis elegans. Pestic. Biochem. Physiol. 2017, 138, 84-90. [CrossRef]

42. Ramos, R.S.; Sedyiama, C.S.; Queiroz, E.A.; Costa, T.L.; Araújo, T.A.; Picanço, M.C. Toxicity of insecticides to Chrysodeixis includens and their direct and indirect effects on the predator Blaptostethus pallescens. J. Appl. Entomol. 2017, 141, 677-689. [CrossRef]

43. Peter, C.; David, B.V. Residual toxicity of some insecticides on groundnut to the first and third instar larvae of Spodoptera litura F. (Lepidoptera: Noctuidae). Int. J. Pest Manag. 1988, 34, 24-26.

44. Kongmee, M.; Boonyuan, W.; Achee, N.L.; Prabaripal, A.; Lerdthusnee, K.; Chareonviriyaphap, T. Irritant and repellent responses of Anopheles harrisoni and Anopheles minimus upon exposure to bifenthrin or deltamethrin using an excite-repelency system and a live host. J. Am. Mosq. Control Assoc. 2012, 28, 20-29. [CrossRef] [PubMed]

45. da Silva Rolim, G.; Plata-Rueda, A.; Martínez, L.C.; Ribeiro, G.T.; Serrão, J.E.; Zanuncio, J.C. Side effects of Bacillus thuringiensis on the parasitoid Palmistichus elaeisis (Hymenoptera: Eulophidae). Ecotoxicol. Environ. Saf. 2020, 189, 109978. [CrossRef] [PubMed]

46. Plata-Rueda, A.; Rolim, G.D.S.; Wilcken, C.F.; Zanuncio, J.C.; Serrão, J.E.; Martínez, L.C. Acute toxicity and sublethal effects of lemongrass essential oil and their components against the granary weevil, Sitophilus granarius. Insects 2020, 11, 379. [CrossRef] [PubMed]

47. Huang, J.; Gut, L.J.; Grieshop, M. Development of a new attract-and-kill technology for oriental fruit moth control using insecticide impregnated fabric. Entomol. Exp. Appl. 2014, 154, 102-109. [CrossRef]

48. Plata-Rueda, A.; Martínez, L.C.; Dos Santos, M.H.; Fernandes, F.L.; Wilcken, C.F.; Soares, M.A.; Serrão, J.E.; Zanuncio, J.C. Insecticidal activity of garlic essential oil and their constituents against the mealworm beetle, Tenebrio molitor Linnaeus (Coleoptera: Tenebrionidae). Sci. Rep. 2017, 7, 46406. [CrossRef] [PubMed]

49. Farder-Gomes, C.; Saravanan, M.; Martínez, L.C.; Plata-Rueda, A.; Zanuncio, J.C.; Serrão, J.E. Azadirachtin affects the respiration and digestion in Anticarsia gemmatalis caterpillars. Toxin Rev. 2021, 1-10. [CrossRef]

50. Plata-Rueda, A.; Menezes, C.H.M.; Cunha, W.S.; Alvarenga, T.M.; Barbosa, B.F.; Zanuncio, J.C.; Martínez, L.C.; Serrão, J.E. Side-effects caused by chlorpyrifos in the velvetbean caterpillar Anticarsia gemmatalis (Lepidoptera: Noctuidae). Chemosphere 2020, 259, 127530. [CrossRef]

51. Castro, B.M.C.; Martínez, L.C.; Plata-Rueda, A.; Soares, M.A.; Wilcken, C.F.; Zanuncio, A.J.V.; Fiaz, M.; Zanuncio, J.C.; Serrão, J.E. Exposure to chlorantraniliprole reduces locomotion, respiration, and causes histological changes in the midgut of velvetbean caterpillar Anticarsia gemmatalis (Lepidoptera: Noctuidae). Chemosphere 2021, 263, 128008. [CrossRef]

52. Silva, W.M.; Martínez, L.C.; Plata-Rueda, A.; Serrão, J.E.; Zanuncio, J.C. Respiration, predatory and prey consumption by Podisus nigrispinus (Heteroptera: Pentatomidae) nymphs exposed some to insecticides. Chemosphere 2020, 261, 127720. [CrossRef]

53. Baumler, R.E.; Potter, D.A. Knockdown, residual, and antifeedant activity of pyrethroids and home landscape bioinsecticides against Japanese beetles (Coleoptera: Scarabaeidae) on linden foliage. J. Econ. Entomol. 2007, 100, 451-458. [CrossRef] [PubMed]

54. Usmani, K.A.; Knowles, C.O. Toxicity of pyrethroids and effect of synergists to larval and adult Helicoverpa zea, Spodoptera frugiperda, and Agrotis ipsilon (Lepidoptera: Noctuidae). J. Econ. Entomol. 2001, 94, 868-873. [CrossRef] [PubMed]

55. Saladini, M.A.; Blandino, M.; Reyneri, A.; Alma, A. Impact of insecticide treatments on Ostrinia nubilalis (Hübner) (Lepidoptera: Crambidae) and their influence on the mycotoxin contamination of maize kernels. Pest Manag. Sci. 2008, 64, 1170-1178. [CrossRef]

56. Carneiro, L.; Martínez, L.C.; Gonçalves, W.G.; Santana, L.M.; Serrão, J.E. The fungicide iprodione affects midgut cells of non-target honey bee Apis mellifera workers. Ecotox. Environ. Saf. 2020, 189, 109991. [CrossRef] [PubMed]

57. Serra, R.S.; Cossolin, J.F.S.; Resende, M.T.C.S.; Arthidoro de Castro, M.; Oliveira, A.H.; Martínez, L.C.; Serrão, J.E. Spiromesifen induces histopathological and citotoxic effects in the midgut of the honeybee Apis mellifera (Hymenoptera: Apidae). Chemosphere 2021, 270, 129439. [CrossRef]

58. Castro, B.M.C.; Martínez, L.C.; Plata-Rueda, A.; Soares, M.A.; Tavares, W.S.; Serrão, J.E.; Zanuncio, J.C. Chlorantraniliprole degenerates microvilli goblet cells of the Anticarsia gemmatalis (Lepidoptera: Noctuidae) midgut. Chemosphere 2019, 229, 525-528. [CrossRef] [PubMed]

59. Terra, W.R.; Costa, R.H.; Ferreira, C. Plasma membranes from insect midgut cells. An. da Acad. Bras. de Ciências 2006, 78, 255-269. [CrossRef] [PubMed] 
60. Marques-Silva, S.; Serrão, J.E.; Mezêncio, J.M.S. Peritrophic membrane protein in the larval stingless bee Melipona quadrifasciata anthidioides: Immunolocalization of secretory sites. Acta Histochem. 2005, 107, 23-30. [CrossRef] [PubMed]

61. Liu, X.; Cooper, A.W.; Zhang, J.; Zhu, K.Y. Biosynthesis, modifications and degradation of chitin in the formation and turnover of peritrophic matrix. J. Insect Phyisiol. 2019, 114, 109-115. [CrossRef]

62. Teixeira, A.D.D.; Marques-Araujo, S.; Zanuncio, J.C.; Serrao, J.E. Ultramorphology of the peritrophic matrix in bees (Hymenoptera: Apidae). J. Apic. Res. 2019, 58, 463-468. [CrossRef]

63. Henry, M.; Cerrutti, N.; Aupinel, P.; Decourtye, A.; Gayrard, M.; Odoux, J.F.; Pissard, A.; Ruger, C.; Betagnoil, C. Reconciling laboratory and field assessments of neonicotinoid toxicity to honeybees. Proc. R. Soc. B 2015, 282, 2110. [CrossRef] [PubMed]

64. Wood, T.J.; Goulson, D. The environmental risks of neonicotinoid pesticides: A review of the evidence post 2013. Environ. Sci. Pollut. Res. 2017, 24, 17285-17325. [CrossRef] [PubMed] 